\title{
A Survey of System Dynamics in B2C E-Commerce Business Model
}

\author{
Jian Chen'1, Yin Tang², Jinyu Yang² \\ ${ }^{1}$ Xinhua School, Sun Yat-Sen University, Shenzhen, China \\ ${ }^{2}$ Management School, Jinan University, Guangzhou, China \\ Email: cici919@126.com, ytang@jnu.edu.c, 810269420@qq.com
}

How to cite this paper: Chen, J., Tang, Y. and Yang, J.Y. (2018) A Survey of System Dynamics in B2C E-Commerce Business Model. Modern Economy, 9, 830-852. https://doi.org/10.4236/me.2018.94054

Received: March 8, 2018

Accepted: April 27, 2018

Published: April 30, 2018

Copyright (c) 2018 by authors and Scientific Research Publishing Inc. This work is licensed under the Creative Commons Attribution International License (CC BY 4.0).

http://creativecommons.org/licenses/by/4.0/

\section{c) (†) Open Access}

\begin{abstract}
Fierce competition in electronic commerce, especially Business-to-Customer (B2C) in mainland China, has fostered the need of research on business model. This paper is to rule out the research line on B2C business model. For static model, three phases, conceptualization, elementalization, and modeling of Business Models, are abstracted. The dynamic evolution of business model research and the introduction of system dynamics in the field of business model research are discussed in particular in the paper, including several mainstream models, such as EBMO, e3-value, and business model canvas, are selectively analyzed. On the basic of that, B2C e-commerce business shows its distinct characteristics. The paper concludes that next stage of the research will focus on quantitative analysis and dynamic model.
\end{abstract}

\section{Keywords}

B2C E-Commerce, Business Model, Value Creation, System Dynamics

\section{Introduction}

China is currently in an important period of economic transformation and upgrading. The role of e-commerce in economic development has attracted much attention. In recent years, the increase in the number of online shopping users in China and the continuous increase in the penetration rate have promoted the rapid development of China's online shopping market. Nowadays, online shopping has become an indispensable act for people's daily lives. According to the "2014 Annual Report of China E-Commerce", the scale of online shopping in China reached 2.8 trillion in 2014, an increase of $47.4 \%$. The growth rate is more than four times the growth rate of retail sales of consumer goods. The size of online shopping accounts for the total retail sales of consumer goods $10.7 \%$. At the 
same time, the number of online shopping users in China reached 360 million, an increase of $20 \%$ over 2013, and the penetration of Internet users increased from $48.9 \%$ in 2013 to $55.7 \%$ in 2014 . Research expects that the e-commerce market will reach 24.2 trillion in 2018. In addition, with the rapid development of the mobile shopping market and cross-border e-commerce, e-commerce companies are actively expanding into third-tier cities, rural markets and even international markets. In the next few years, China's online shopping market will still maintain a growth rate of over $30 \%$.

B2C (Business to Consumer, business-to-consumer) will continue to be the main thrust of the future development of China's online shopping market, and it is expected that B2C will account for more than $65 \%$ of the total in 2018 . According to the "2015 Information Economy Report" released by the United Nations Conference on Trade and Development, China has become the world's largest B2C e-commerce market. According to the statistics of Internet Retailer, an authoritative e-commerce magazine of the United States, among the 500 largest online retailers of the year in Asia in 2015, 266 were headquartered in China, more than half. China's online retail (i.e. B2C) market is highly competitive. In the domestic B2C market, Tmall's transaction volume accounted for more than $60 \%$ in 2014 , Jingdong accounted for $19.5 \%$, and the remaining B2C companies traded in Vipshop, Suning Tesco, Gome Online, Dangdang, and Amazon China. The proportion of each accounted for no more than $3 \%$, and the B2C e-commerce market in China showed a pattern of "one super-strong and one strong". Other B2C e-commerce companies are looking for their own living space in the industry.

How B2C e-commerce companies stand out in fierce market competition, in addition to their own strengths, the Business Model has become an important factor. Under the e-commerce environment, the business model is the source of the company's core competitiveness [1] [2]. It is the structural logic for the company to maintain its core competitiveness [3]. It is also an enterprise to customers that provide greater value to outperform competitors [4] [5]. The management guru Peter Drucker believes that the competition among modern enterprises has changed from the competition between products and products to the competition between business models. The so-called business model refers to the method by which an enterprise conducts business activities. As a result, the company gains revenue and maintains its survival and development. An important feature of e-commerce is its ability to continuously generate new business models [6]. Alibaba, companies such as Vipshop have a unique and highly competitive business model. The concept of business model is widely concerned with the rapid development of e-commerce, and $\mathrm{B} 2 \mathrm{C}$ as one of the main modes of e-commerce, its business model is obviously different from the traditional enterprise.

Although the research on the business model expression model has developed rapidly in recent years, a fundamental problem in the study is still not well un- 
derstood: how the business model evolves and develops as the company continues to create value [7]. That is, the current business model research does not focus on the research of its development process and dynamic evolution, leading companies and managers to fail to understand the elements behind the business model and their interrelationships, and thus fail to understand how to use business models to guide the success of the business [8].

In the study of the elements of the business model, changes in factors such as economics, competition, etc. will enable companies to change the components of the business model, which in turn will change the business model of the business [9]. Due to the complex relationship between the constituent elements and elements in the business model, researchers and managers understand the dynamic process of the $\mathrm{B} 2 \mathrm{C}$ e-commerce business model, paying particular attention to the important issues such as the relationship between the elements and the dynamics of the entire system [5]. Although different scholars put forward different expression models based on different perspectives, most of the existing business model expression models still belong to static analysis [10] [11] [12]. This article attempts to sort out the business model of B2C e-commerce companies, especially the dynamic evolution mechanism. The following part of the paper will be determined from the concept, and the development of the study of the business model will be divided into stages and concluded.

The article is organized as follows: Right after the concepts of business model, the stages of business model research is introduced, followed by e-commerce business model research. Dynamic evolution of business model research and the introduction of system dynamics in the field of business model research is payed special attention, before the conclusion part.

\section{Concepts}

\subsection{The Concept of Business Model}

The Business Model first appeared in the paper in 1957 [13]. With the rapid development of the Internet and e-commerce, the business model has attracted wide attention from the business community and academia [14], and gradually formed an independent research area. But so far, the academic community has not reached a consensus on the conceptual nature of the business model [3] [8] [15] [16], which also hindered further research development. Different scholars often define and interpret business models in different research fields from different perspectives. Zott and Amit et al. [16] found that 37\% of articles did not have business models by sorting out articles on business models between 1975 and 2009. For accurate definitions, about $44 \%$ of the articles accurately define or conceptualize the business model, while the remaining $19 \%$ of the articles refer to the definition of the business model by other scholars. In the definition or conceptualization of these business models, Zott and Amit et al. [16] classify the definition of business models as statements, descriptions, expressions, struc- 
tures, conceptualization tools or models, structural modules, frameworks, and models. Table 1 summarizes the definition of business model for scholars who have long been engaged in business model research.

\subsection{Concepts of E-Commerce Business Model}

The intuitive understanding of the term e-commerce is "electronically doing business", which includes electronic commerce, electronic markets, and Internet-based businesses [25]. With the advent and rapid development of e-commerce in the mid-1990s, scholars and business practitioners have rapidly increased their interest in researching business models [14] [16] [26]. Ghaziani and Ventresca [27] combed articles governing the business model from 1975 to 2000 in the management journals. Of the 1729 articles searched, 1563 were published in 1995-2000; followed by Zott and Amit et al. [16]. The findings also confirm this point. Among the articles on business models searched by nine top management

Table 1. Definitions of business model.

\begin{tabular}{|c|c|}
\hline Literature & Definition \\
\hline Amit and Zott's [4] & $\begin{array}{l}\text { Business model is a transactional content, structure, and governance structure that uses business opportunities to } \\
\text { create value, and describes the way networks are made up of companies, suppliers, alternates, and customers. }\end{array}$ \\
\hline Applegate [17] & $\begin{array}{l}\text { Business model is a description of a complex company that can describe the company's structure and the } \\
\text { interrelationships between the elements and how the company responds to the real world. }\end{array}$ \\
\hline $\begin{array}{l}\text { The Shafer and Smith } \\
\text { et al. [19] }\end{array}$ & $\begin{array}{l}\text { Business model is the essential expression of the company's core logic and is a strategic choice for creating and } \\
\text { acquiring value from the value network. This definition contains four key elements: strategic choice, value } \\
\text { network, value creation, and value obtain. }\end{array}$ \\
\hline $\begin{array}{l}\text { Morris and } \\
\text { Schindehutte et al. [20] }\end{array}$ & $\begin{array}{l}\text { The business model is a simple statement that shows how companies can position and integrate a set of internally } \\
\text { correlated variables in strategic direction, operational structure, and economic logic in order to establish a } \\
\text { competitive advantage in a particular market. }\end{array}$ \\
\hline Yuan Lei [13] & $\begin{array}{l}\text { Business model describes how an enterprise designs four factors: value proposition, value network, value } \\
\text { maintenance, and value realization. Based on the creation of customer value, it serves as other stakeholders such as } \\
\text { shareholders and partners. Create value. }\end{array}$ \\
\hline $\begin{array}{l}\text { Johnson and } \\
\text { Christensen et al. [8] }\end{array}$ & $\begin{array}{l}\text { The business model consists of four closely linked elements that together create and deliver value. These four } \\
\text { elements are customer value propositions, profit models, key resources, and key processes. }\end{array}$ \\
\hline $\begin{array}{l}\text { Wei Wei and Zhu } \\
\text { Wuxiang [21] }\end{array}$ & $\begin{array}{l}\text { The business model is essentially a transaction structure. The complete business model system includes } \\
\text { positioning, business systems, key resource capabilities, profitability models, free cash flow structure, and } \\
\text { corporate value. These six aspects are mutually exclusive. Influences constitute an organic business model system. }\end{array}$ \\
\hline Zott and Amit [23] & $\begin{array}{l}\text { Business model is a model for businesses to conduct business. This model illustrates how companies provide value } \\
\text { to stakeholders and how they relate to factors and product markets. }\end{array}$ \\
\hline $\begin{array}{l}\text { Fuller and Haefliger's } \\
\qquad[24]\end{array}$ & $\begin{array}{l}\text { Business model is a system that solves the problem of determining who the customer is, what the customer needs, } \\
\text { and what is providing the customer with a satisfying and measurable value. The business model consists of four } \\
\text { core elements: customer confirmation, customer demand, value transfer, and Contact, value acquisition. }\end{array}$ \\
\hline
\end{tabular}


journals and three practical management reviews, the research on business models from 1995 to 2010 showed explosive growth. Therefore, this paper believes that the emergence and popularity of the concept of business model is closely related to the development of e-commerce and the Internet. Many scholars have also confirmed this view. Shafer and Smith et al. [20] analyzed published literature on business models from 1998-2000 and found that 8 out of the 12 definitions of business models are related to e-commerce. Zott and Amit et al. [16] also obtained the same conclusion. In the 1975-2009 literature, 49 articles that defined the business model accurately and clearly, more than $1 / 4$ of articles were defined in relation to e-commerce.

In the 1990s, IBM put forward the term "E-business model (E-commerce model, Electronic Business Model)" for the first time. The e-commerce business model refers to the use of the Internet. Technology revolutionizes key business processes [28]. As one of the earliest foreign scholars to study business models, Timmers [29] believes that the e-commerce model is the structure of products, services, and information flow. It includes the description of different business participants and their roles, the potential benefits of different business partners, and the source of income. In three aspects, $11 \mathrm{e}$-commerce business models such as electronic stores and e-procurement have been defined. Weill and Vitale [30] believe that the e-commerce business model is a description of the roles and relationships between the consumers, customers, partners, and suppliers of an enterprise. Through this description, the main product flow and information flow can be accurately defined. And income streams, as well as the main benefits gained by different players. Amit and Zott [4] believe that the e-commerce business model includes three elements: transaction content, transaction structure, and transaction governance. While Chi-Yo Huang and Shyu [31] believe that the e-commerce model is a market competition strategy and the entire electronic transaction process business process structure, the electronic transaction process includes marketing and advertising, negotiation, procurement, product or service provision process, security Payment methods, after-sales services and after sales analysis. Teece [22] defines the B2C business model of telecommunications companies as: The telecommunication companies integrate the value network partners such as service providers and equipment manufacturers through e-commerce technologies to create the core logic of value creation and value for the public customers.

\section{Research Stages of Business Model}

At present, research on business models can be divided into three stages: conceptualization, elementalization and modelling [32]. These three stages are not strictly divided by time, and each stage has more or less overlap. In part, it also shows that different scholars use different research methods to study business models based on different research perspectives. Their purpose is to further explain the basic question of what business model is. 


\section{1) Conceptualization of Business Models}

In the early stage of business model research, scholars generally adopted the concept of business model to define the concept of business model, which laid the foundation for the later research on the elementalization of business model and the expression model. Timmers [28] believes that the business model is the structure of a company's product flow, service flow, and information flow, and the operating mechanism of its value creation process. Stewart and Zhao [33] believe that the business model is a logical statement that companies can obtain and maintain their revenue stream. Weill and Vitale [23] believe that the business model defines the product flow, information flow, and income flow of the enterprise, and describes the role relationships and major interests of each participant. Afuah [9] believes that "the business model is the way companies make money" and is the sum of the activities that companies engage in order to obtain profits.

2) Research on Elementalization of Business Models

With the in-depth study of the business model by scholars, some scholars have gradually adopted elementalization to express business models and concretely define the concept of business models. Although this stage of research just lists the constituent elements of the business model, ignoring the study of the relationships between the elements, these research results have provided a wealth of lessons for the subsequent expression model research. This article collates relevant literature on the study of the elementalization of business models (Table 2).

3) Research on Modeling of Business Models

The "business model" is translated from the English vocabulary "Business Model". The English word "Model" itself has the meaning of "model." Based on the research results of the elementalization of the business model, in order to further reveal the structural or logical relationships between the different

Table 2. Elements of the business model.

\begin{tabular}{|c|c|c|c|}
\hline Literature & Components & Number & scope \\
\hline Mahadevan [25] & Value Stream, Income Stream, Logistics & 3 & Electronics \\
\hline Alt and Zimmerman [34] & Mission, Structure, Process, Revenue, Legal Obligations, Technology & 6 & Electronics \\
\hline Afuah and Tucci [1] & $\begin{array}{l}\text { Customer Value, Scope, Price, Revenue, Related Behavior, Implementation } \\
\text { Capability, Sustainability }\end{array}$ & 7 & Electronics \\
\hline Weill and Vitale [30] & $\begin{array}{l}\text { Strategic Goals, Value Propositions, Revenue Sources, Success Factors, Channels, } \\
\text { Core Competencies, Target Customers, IT, Technical Facilities }\end{array}$ & 9 & Electronics \\
\hline Amit and Zott $[4]$ & Transaction content, transaction structure, transaction governance & 3 & Electronics \\
\hline Rayport and Jaworski [35] & Value Stream, Market Space Offerings, Resource Systems, Financial Models & 4 & Electronics \\
\hline
\end{tabular}

Source: Mainly based on literature [20] (Morris, 2005) and [13] (Yuan Lei, 2007), 2016. Note: “Scope" refers to the researcher's field of vision, which aims to distinguish between the general business model research and the business model of the network electronics industry [13]. 
elements of the business model, scholars have used modeled expressions to express the business model. The comparatively influential models of business model expression abroad include: bridging model [10], operational system model [4], EMBO model (E-Business Model Ontology) [11], core logic Models [19], Heuristic Logic Modules [37], Four-Element Models [8], RCOV Models [38], Two-Element Models [39], Looped Logical Model [22]; Domestic comparatively influential business model expression models include: "3-4-8" constitutes a system business model [13], and a six-factor business model [21], theoretical model of EREV business model [40].

Hamel's bridging model first proposed a bridging business model. This model started the modelling of business models. It first included customers in the expression model of business models; Shafer's core logic model was studied from the perspective of strategic management. The subjectivity of the business model; Osterwalder's EBMO model describes the interrelationships of the constituent elements; Johnson's four-factor model emphasizes the important role of key resources and key processes in the business model, and reveals the causal logic in the business model elements. The coordination, complementarity, and interaction between the elements are fundamental to the business model's ability to play an important role. Yuan Lei [13] believes that the business model is fundamentally the logic of corporate value creation and proposes a "3-4-8" compositional system for business models. At present, the research of the business model expression model is in the diversified stage of "hundred flowers blossoming and a hundred schools of thought contend" [32]. So far no expression model has been unanimously approved by scholars. At the same time, many business models express models in the elements. There is still a lot of ambiguity in the cognitive aspect, and in particular the failure to clarify the theoretical relationship between elements has made it difficult for business models to solve practical problems [40].

4) Research on Dynamic Modeling of Business Models

Based on the modelling of business models, it has become more and more important to observe the growth of a company. Traditional static models are incapable of doing so. In recent years, academic circles have gradually begun to study dynamic models.

\section{Research on E-Commerce Business Model Expression}

\subsection{Research on E-Commerce Business Model Expression}

The e-commerce business model is composed of a series of elements, so it is necessary to use a specific framework to define the relationships between the elements [41]. Zott and Amit et al. [16] consider the two complementary directions of the business model in e-commerce: the general e-commerce model and the components of the classification criteria and e-commerce model. In the study of the constituent elements of the e-commerce model, scholars mainly express models from business models [4] [30] [34] [40] [42] [43] [44] [45], Strategic 
Marketing of Electronic Commerce [46] [47] [48] [49] [50] studied these two themes. Scholars based on different research purposes and research perspectives, put forward different e-commerce business model expression models, although these models are somewhat different, and some only minor differences, but the elements of the model and the basic relationship between the elements are quite different. This article collates the relevant research literature of the e-commerce business model expression model. Table 3 lists the constituent elements of the e-commerce business model expression model.

\subsection{Research on E-Commerce Business Model Expression from the Perspective of Value Creation}

Although the study of business models has received extensive attention from scholars and the business community, academic circles have so far failed to reach a consensus on the basic question of what is a business model. Different scholars often study business models based on different fields and research perspectives. Different models or constituent elements have also been proposed in the study of e-commerce business model expression models. The same conclusion can also be drawn from the comparison of the constituent elements of different expression models listed in Table 3. This paper sorts out the research literature on e-commerce business model expression models from 2000 to 2015 and finds that about $80 \%$ of the research perspectives in these research literatures are value creation perspectives [54], which has also been proved in other authors' literature studies. [13] [55] (Table 4).

Value was redefined in the era of digital economy, so more and more scholars tried to use the concept of business model to explain how companies create value in the online market [23]. In the current business model research, the value creation perspective has the most extensive and influential research [8] [22] [56] [57] [58] [59] is one of the research trends of the current business model [55].

Table 3. Components of the e-commerce business model expression model.

\begin{tabular}{|c|c|c|}
\hline Literatures & Components & Number \\
\hline Gordijn and Akkermans [43] & $\begin{array}{l}\text { Participants, Value Objectives, Value Ports, Value Creation, Value Interface, Value } \\
\text { Exchange, Target Customers }\end{array}$ & 7 \\
\hline Amit and Zott [4] & Efficiency, Complementarity, Lockdown, Novelty & 4 \\
\hline $\begin{array}{l}\text { Dubosson-Torbay and Osterwalder } \\
\qquad \text { et al. [51] }\end{array}$ & Products, Customer Relationships, Partner Foundations and Networks, Finance & 4 \\
\hline $\begin{array}{l}\text { Van Der Vost and Van Dongen } \\
\qquad \text { et al. }[52]\end{array}$ & Value proposition, participant roles, processes, functions, applications features & 6 \\
\hline Osterwalder and Pigneur [44] & Product Innovation, Customer Relationships, Internal Management, Finance & 4 \\
\hline Desai and Currie [53] & $\begin{array}{l}\text { Market Positioning, Customer Expectations, Value Propositions, Products and Services, } \\
\text { Revenue, Delivery Models }\end{array}$ & 6 \\
\hline Grant $[40]$ & $\begin{array}{l}\text { Relationships, Key Business, Core Resources, Revenue Sources, Cost Structure 9. Source: } \\
\text { Author finishing }\end{array}$ & 9 \\
\hline
\end{tabular}


Table 4. Comparison of perspectives on e-commerce business model expression model.

\begin{tabular}{cccl}
\hline Perspective & Number of Articles Percentage & \multicolumn{1}{c}{ Representative Model } \\
\hline $\begin{array}{c}\text { Value Creation } \\
\text { Perspective }\end{array}$ & 48 & $80 \%$ & $\begin{array}{l}\text { Osterwalder's E-commerce Business Model Ontology } \\
\text { Model (EBMO), Gordijn's e3-value model }\end{array}$ \\
$\begin{array}{c}\text { Other } \\
\text { Perspectives }\end{array}$ & 12 & $20 \%$ & $\begin{array}{l}\text { Hedman model, Papakiriukopoulos model, Bouwman } \\
\text { model, Werner's FOCAL model, Brousseau model }\end{array}$ \\
\hline
\end{tabular}

Zott and Amit [23] believe that the study of value creation perspective is conducive to enhancing the dynamic and systematic understanding of business models.. Zhang Jingwei and Wang Yingjun [55] analyzed and found that the "value triangle" framework is helpful to understand and perspective the logical relationship between value definition, value creation and transmission, and value acquisition in business models. In the study of e-commerce business models, researchers have studied value concepts (such as value stream, customer value, value proposition), financial aspects (such as income stream, cost structure), and enterprises and customers or partners to varying degrees. The value-network-related aspects (such as value-passing channels, network relationships, etc.), which are components of the generic business model structure model (or expression model) [16].

Amit and Zott [4] believe that the business model consists of three elements: "content, structure, and governance." The potential for value creation depends on four mutually complementary and independent design themes: efficiency, complementarity, locking, and novelty. Any value-driven theme of value-driven can provide guarantees for the effectiveness of the other three value-driven themes. Enterprises create value for stakeholders in the development of opportunities. Magretta [60] believes that the business model is a series of ideas for how a company can serve its customers and all participants who maintain the normal operation of the company by creating value. Linder and Cantrell [61] believe that the business model is the core logic of the organization to create value. Amit and Zott [62] and Casadesus-Masanell and Zhu [63] believe that the business model represents the logic of the company to create, acquire and distribute value. Osterwalder and Pigneur [64] and Suarez and Cusumano et al. [65] believe that the business model is the basic principle for the organization of value networks and the creation, transmission and acquisition of value.

Through the analysis of the constituent elements of the e-commerce business model expression model (Table 3), we can see that in the perspective of value creation, value proposition (representing "value definition" as the same as "value proposition"), value creation, Value transmission (refers to "value network" and "value network" as the same meaning as "value transfer"), value acquisition ("value realization", "finance aspect", "profit model", "income model", "acquisition "Value" is considered to have the same meaning as "value acquisition." It is the four most frequently occurring elements. Through further analysis, it can be found that these four elements can just form an organic whole and thus consti- 
tute the core elements of the business model. This is also proved by other scholars' studies. Peters and Blohm et al. [66] believe that although the constituent elements of the business model expression model are different, their constituent elements can be value proposition, value co-creation model, value transfer, value acquisition. Four dimensions to analyze. Wei Jiang and Liu Yang [58] believe that the core of the business model is customer value proposition, value creation, and value acquisition.

The value proposition clarifies what value the company provides to its target customers and reflects its value commitment to customers [8] [55]. It identifies the profit and loss of customers and is the closest module for business models to connect with customers [67]. Overall, Osterwalder and Pingeur et al. [11] believe that value proposition is the value that an enterprise can provide to its customers through its products and services. The updated adjustment of customer value propositions helps enterprises create value, transmit value, and obtain value. Johnson and Christensen et al [8] proposed a four-element model of business models in which customer value propositions aim to describe how companies can help customers accomplish important tasks, including target customers, tasks to be accomplished, and three subcomponents of offering. One of the constituent elements of the "3-4-8" constitution of the system business model of Yuan Lei [12] is the value proposition that when a company puts forward a value proposition, it must fully consider its own strategic resources and core competencies, and on this basis found a new combination of elements and applications to achieve value innovation [68].

Value creation and delivery describe how companies can create value for their customers by integrating internal and external key resources, and use internal processes to deliver value propositions and profitability to target segments [55]. Huff and Floyd et al. [69] believe that value creation is the result of resource transformation. Enterprises transform intangible and tangible resources into products or services that customers need. Amit and Zott [4] believe that the business model is an analytical unit of value creation. Johnson and Christensen et al [8] believe that the various elements of the business model work together in the process of value creation and acquisition.

Value acquisition describes how the company obtains value by meeting the needs of its target customers and creating and delivering value for its customers, indicating the process or mechanism by which the company obtains a certain share of the total economic value of output [8] [55]. This process is a cycle of enterprise value creation activities. Only gaining value can make the entire business model continue to operate and maintain the competitiveness of enterprises. Johnson [70] argues that value acquisition describes how companies convert value propositions into revenue streams, and businesses gain profits. Value acquisition is based on the revenue model and cost structure, where revenue stream is the product of the product's price and quantity, and costs include both direct and indirect costs. Yuan Lei [68] believes that value realization (value ac- 
quisition) is the end of the business model, and any business model must ultimately come down to the most primitive problem of how the company is profitable. Core Logic Models [19], Heuristic Logic Modules [36], Four-Element Models [8], RCOV Models [37], Two-Element Models [38] and the circular logic model [22] all use value acquisition as one of the key elements of the model ("profit model", "get value", "cost and profit", "value floatation mechanism", etc. Elements or building blocks are considered to have the same meaning as "value acquisition."

E-commerce Business Model Expression Model Based on Value Creation Perspective In the literature, about $50 \%$ of the article's expression models are cited or borrowed from Osterwalder's EBMO model [54]. In addition, other scholars also use Goridijn's e3-value model to study the e-commerce business model. Refer to Table 5 for specific references. Among them, EBMO, e3-value, and business model canvases have a greater influence.

EBMO e-commerce business model Osterwalder and Pianeur et al. [11] proposed the EBMO model (E-Business Model Ontology) based on the four dimensions of product innovation, customer relationship, internal management, and finance. More detailed nine component elements (Table 6), the EBMO model uses network modeling from the perspective of value creation to describe in detail the various elements of the e-commerce business model [12], and the constituent elements. The relationship between his models has been widely used in the study of e-commerce business model expression models and has been used by many scholars for reference (eg, Kiani and Gholanmian et al. [71]; Wu and Ma et al. [72]; Zilber and Araujo, [73]; Zhang and Williams et al. [74]; Grant, [41]; Giannoutakis and Li, [75]).

Kiani and Gholanmian et al. [71] borrowed the EBMO model and used the causal loop diagram (CLD) method to analyze the structure of the enterprise's e-commerce system so that managers and related employees could deeply understand the e-commerce business model. Wu and $\mathrm{Ma}$ et al. [72] draw on the EBMO model to conduct case studies to study how emerging companies in emerging economies are under technological and market resource disadvantages.

Table 5. Analysis of reference and citation of e-commerce business model model from the perspective of value creation.

\begin{tabular}{|c|c|c|}
\hline Literature & Model Components & citations \\
\hline $\begin{array}{l}\text { Osterwalder and } \\
\text { Pigneur [18] }\end{array}$ & $\begin{array}{l}\text { Product Innovation (Value Proposition), Customer Relationships } \\
\text { (Target Customers, Sales Channels, Relationships), Internal } \\
\text { Management (Value Allocation, Capabilities, Partnerships), } \\
\text { Financial Aspects (Cost Structure, Revenue Models) }\end{array}$ & 21 \\
\hline $\begin{array}{c}\text { Gordijn and } \\
\text { Akkermans }[43]\end{array}$ & $\begin{array}{l}\text { Participants, Value Objects, Value Ports, Value Interfaces, Value } \\
\text { Exchange, Value Providers, Market Groups, Cooperative } \\
\text { Operators, Value Activities }\end{array}$ & 7 \\
\hline \multicolumn{2}{|c|}{$\begin{array}{l}\text { Other authors (authors build models or articles that borrow from other models and } \\
\text { are cited no more than two times) }\end{array}$} & 15 \\
\hline
\end{tabular}


How can they use the disruptive technologies of advanced countries to innovate business models to better serve them? Customers create value and ultimately make the business successful. For research gaps between disruptive technologies and business model innovations by latecomers in emerging economies, Zilber and Araujo [73] study the adoption of e-commerce in small businesses in Latin America and use the EBMO model to study quantitative differences in business models. The role of the element and the factors has a key influence on the adoption of e-commerce. Grant [40] uses the EBMO model to analyze the e-commerce model of large-scale real estate platforms. Through analyzing the similarities and differences in e-commerce business models, it explains how these e-commerce business models affect the success of enterprises. Differences include different sources of income and cooperation. The degree of partnership and the role of these partners in business success. Giannoutakis and Li [75] emphasized the important role of information and communication technologies (ICT) and the Internet for Intelligent Transportation Systems (ITS), and therefore proposed an e-commerce model applicable to the development of intelligent transportation system technologies to address the issue of sustainable development of ITS companies and The problem of network economy, and put forward the analysis framework of stakeholders.

The e3-value e-business model the e3-value model of Gordijn and Akkermans [43] constructs an e-commerce model ontology of the exchange network of value core, value creation, and value among participating entities. This model includes participants, value objects, the value port, value interface, value exchange, value provision, market groups, cooperative operators, and value activities are seven constituent elements. The e3-value model abstracts the simplified model of value creation and is used well [76] [77] [78] [79] (eg, Ouyang Feng and Zhao Hongdan, [76]; Ouyang Feng, [77]; Peng Dinghong and Jia Tingting, [78]; Glova and Sabol et al., [79]). Gordijn's e3-value modeling method is to provide a value-based research method. This method analyzes the constituent systems of business models and models the value-based transaction activities in the system to explain who the participating entities provide economic value for. And what benefits are obtained [43]. Ouyang Feng and Zhao Hongdan et al. [76] used e3-value for structural analysis to study the e-business model of data service providers and to model value creation, value addition, and exchange among different participants by establishing value models. It suggests the intrinsic motivation mechanism of the e-commerce model. Afterwards, Ouyang Feng [77] used e3-value to analyze the value model of e-book online publishing business model, obtained the relevant parameters by using the survey method, and entered the model. Then the value model was simulated by trial to obtain the participants. The corresponding income calculation table and economic feasibility evaluation, Peng Dinghong and Jia Tingting et al. [78] used e3-value as a research method to construct a value model for a value-chain-based mobile business model. Input parameters into the model and conduct a simulation trial to make profitability 
and rationality of the business model. Evaluation, this e3-value model is conducive to the innovation of key factor value activities and the deconstruction of the value interface and value port, so as to obtain the value model of the mobile business value network business model.

The business model canvas Osterwalder and Pigneur [44] proposed the EBMO model based on the four dimensions of product innovation, customer relationship, internal management and finance (Figure 1), identified the 9 key elements of the model, and conducted A detailed description. In 2010, Osterwalder and Pigneur [64], who have been engaged in research on business models for many years, proposed the Business Model Canvas (BMC). Through the systematic collation and induction, nine building blocks were finally identified and these nine basic structures were considered The block can describe and define the business model well and show the logic of the enterprise to create income (value creation) (Table 6).

Building Block 1: Customer Segments the Customer Segments building block is used to depict the different groups or organizations that a business wants to reach and serve. The customer is the core element of the business model. Without a (profitable) customer, the company cannot achieve sustainable development. In

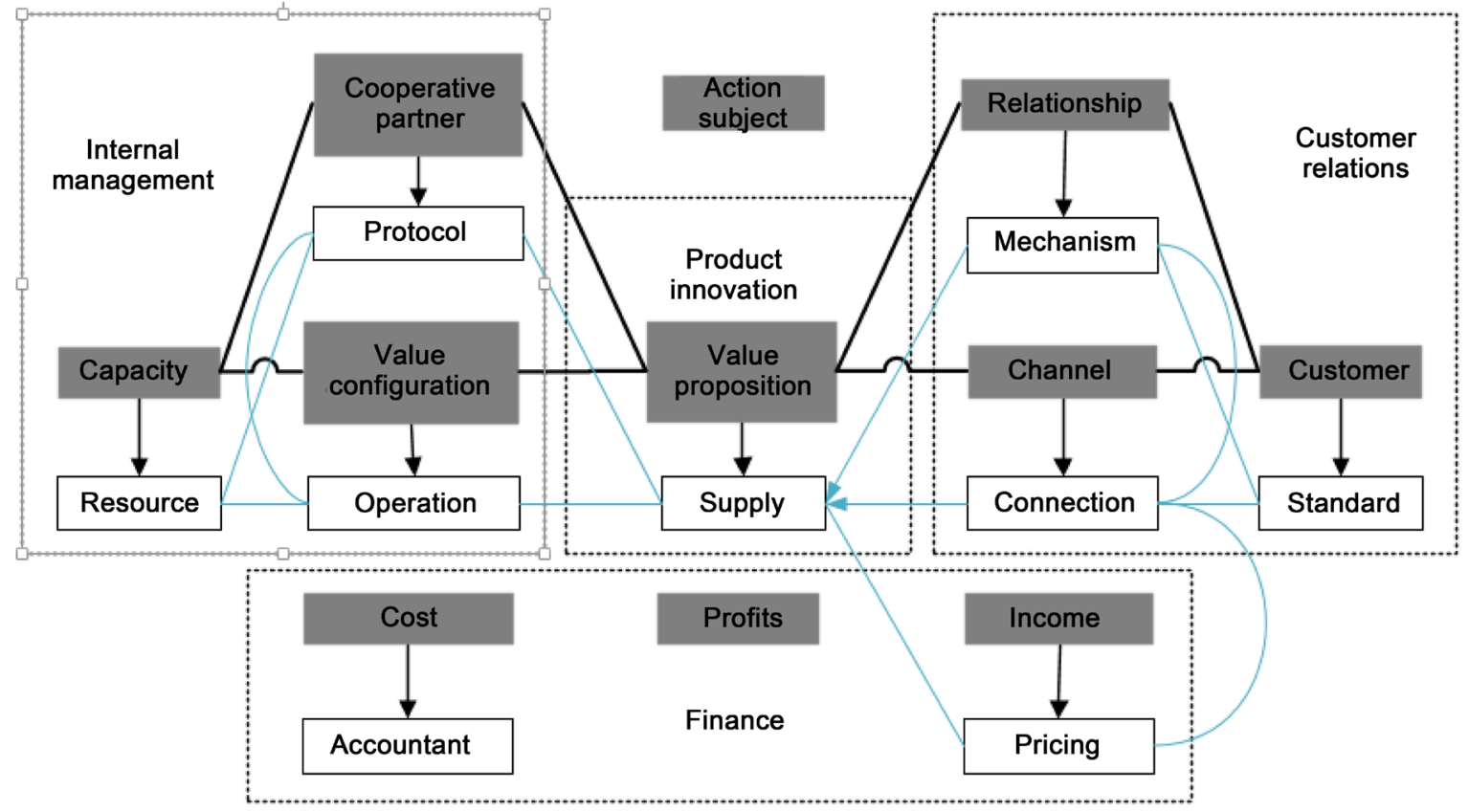

Source: Osterwalder and Pianeur et al. [11], 2005.

Figure 1. The EBMO model.

Table 6. The BMC model of Osterwalder and Pigneur.

\begin{tabular}{cccc}
\hline \multirow{2}{*}{ Key Partnerships } & Key Activities & Value Propositions & \multicolumn{2}{c}{ Customer Relationships } \\
\cline { 2 - 2 } Key Resources & & Channels \\
\hline \multicolumn{3}{c}{ Cost Structure } & Revenue Streams \\
\hline
\end{tabular}

Source: The New Generation of Business Models (Osterwalder and Pigneur, translated by Wang Shuai, 2010, pp. 4-35). 
order to better satisfy customers, companies divide customers with common needs, behaviors, and other attributes into different segments. Customers in each segment are called customer segmentation groups. There are different types of customer segmentation groups. Enterprises define the customer segmentation groups of the business model and decide which customer segment groups provide products and services.

Building Block 2: Value Propositions Value propositions are used to describe the series of products and services that create value for specific customer segments. The value proposition allows a customer to select and retain the company by not satisfying the user's needs or solving the customer's problem without turning to another company. Each value proposition meets the needs of a specific customer segmentation group, thereby providing customers with an optional series of products or services. Through this combination, the company creates value for its customers. Values are both quantitative and qualitative. Factors such as novelty, performance, customization, design, price, and brand/identity status can help create value for customers.

Building Block 3: Channels The Channel Access Building Blocks describe how a company communicates, communicates its customer segments, and communicates its value proposition. The company contacts and communicates with customers through channel channels, and distributes and sells products or services to customers. Channel channels play an important role in customer experience. The company communicates value propositions to customers through channels to help increase the company's product and service awareness among customers, assist customers in purchasing specific products or services, and provide after-sales support to customers.

Building Block 4: Customer Relationships the Customer Relationship Building Blocks are used to depict the type of relationship established by a company with a specific customer segmentation group. Based on customer acquisition, customer retention, sales increase, and other reasons, companies can establish different types of relationships with different segments. These relationships can be either individual or automated. Customer relationships have a profound impact on customer experience, so companies must manage customer relationships. The types of relationships between companies and customers include personal assistants, dedicated personal assistants, self-service, automated services, communities, and collaborative collaboration.

Building Block 5: Revenue Streams the Revenue Sources building block is used to depict the company's cash income from each customer group (requires cost deductions from revenue generation). The source of income is the artery of the business model, and the company can only discover one or more sources of income in each customer segment by knowing what kind of value makes each customer segmentation group truly willing to pay. Each revenue source may have different pricing mechanisms. A business model can include two different types of revenue sources: one is through transaction revenue obtained through a 
one-time payment by customers; second is that recurring income comes from to obtain value proposition and after-sales service. And continue to pay for the cost.

Building Block 6: Key Resources the Core Resources Building Blocks are used to depict the most important factors necessary to make the business model work effectively. Each business model requires core resources that enable organizations to create and deliver value propositions, reach the market, establish relationships with customer segmentation groups, and earn revenue. Core resources include several types of physical assets, knowledge assets, human resources, and financial assets. Sources of core resources include: company-owned, company-rented, and key partners.

Building Block 7: Key Activities the Key Business Building Blocks are used to depict the most important things companies must do to ensure that their business model is feasible. The continuous operation of the business model requires a variety of different key business activities. It is the basis for creating and providing value propositions, access to markets, and maintaining customer relationships and revenues. Companies can successfully operate through the implementation of these most important businesses. Differences in business models can make a difference in the company's business-critical business. Key businesses include product manufacturing, problem solving, and platform/networking.

Building Block 8: Key Partnerships Key Partnerships An important collaborative building block is used to portray the networks of suppliers and partners that are needed to make business models work effectively. Companies may establish cooperative relationships with other companies based on optimizing business models, reducing risks, and acquiring resources. These partnerships are increasingly becoming the cornerstone of many business models. Cooperation relationships can be divided into four types: strategic alliance relationships (non-competitors, Co-opetition (strategic partnerships between competitors), joint ventures (development of new business), buyer-supplier relationships (assurance of reliable supply).

Building block 9: Cost structure the cost structure building block is used to depict all the costs incurred in operating a business model. The main types of costs are fixed costs and variable costs. Costs can be incurred by creating value and providing value, maintaining customer relationships, and generating revenue. Business model cost structure types include cost-driven and value-driven, cost-driven business models focus on reducing costs as much as possible in every place, value-driven business model is focused on creating value, less concerned about its business model Design impact on costs.

\section{The Dynamic Evolution of Business Model Research and the Introduction of System Dynamics in the Field of Business Model Research}

Although research on business model expression models has developed rapidly 
in recent years, a fundamental problem in research is still not well understood: how business models evolve and develop when companies continue to create value [7]. That is, in the study of the business model, the development process and the dynamic evolution of the business model are not concerned, leading enterprises and managers to fail to understand the elements behind the business model and their interrelationships, thus failing to understand how to use the business model to guide the success of the company [8]. Different scholars propose different business model expression models based on different research purposes and research perspectives. Most of the existing business model expression models still belong to static analysis [10] [11] [12]. Hamel's bridging model opened the door to the modelling of business models, analyzed the constituent elements of the business model from a static perspective of the business, and described the factors involved [12]. Shafer's core logic model studies the subjectivity of the business model from the perspective of strategic management. Shafer's core element model studies the role and positioning of competition in the business model from a qualitative perspective. Osterwalder's EBMO model describes the interrelationship of the constituent elements, analyzes the business model from a static perspective, and ignores the dynamic evolution of the business model [32].

The study of dynamic evolution of business models [7] [8] has received the attention of scholars in recent years. Li Xuerong and Zhang Xiaoxu et al. [3] combed business model research literature and found that theoretical research is quantitative. It is one of the three major research trends in the business model. Even so, most studies of business models still focus on the concept of business model to discuss its changes [80], less to discuss how the business model itself changes, the current research on business model changes pay more attention to its constituent elements, but ignore the components Research on interrelationships [14] [27]. Zhang Jingwei [81] according to the 2010 issue of Long Range Planning, a special issue on business models, concluded that there are three main theoretical theories in the dynamic study of business models: the interactive evolution of business model elements, the orientation of trial and error learning, and adaptation Change process/model.

Johnson's four-factor model studies the elements of the business model and the interrelationship between the elements, and uses a qualitative approach from a strategic perspective to illustrate the complex dynamics and evolution of the business model. The structure of the "3-4-8" business model proposed by Yuan Lei [13] was innovative and made a profound qualitative analysis of the structure of the business model and the interrelationships between the internal factors and the internal evolution of the expression model. Achtenhagen and Melin et al. [7] learn from the perspective of dynamic capabilities and strategic practices to study the important supporting role that the three key dynamic capabilities of business models play in the creation of corporate value in the course of time. The key elements in the process of creating value and the process of change, and 
the key issues that needs to be addressed. Demil and Lecocq [37] used the RCOV framework to analyze the evolution of the business model and the dynamic behavior of the interactive evolution of the elements of the business model. The ten-year development of the Arsenal is used as a case to demonstrate the effectiveness of the model.

In order to further study the dynamic evolution of the business model qualitatively and quantitatively, some scholars have adopted the research methods of network modeling to study the elements of the business model, the status of the factors, and the relationship between the elements [13]. Some scholars tried to use the system dynamics method to study the dynamic evolution of business models. Dong Shuang [82] established a telecommunication business model system dynamics model based on value net, and used a combination of quantitative and qualitative, static and dynamic research methods for each subsystem. The interactions were studied. Grasl [83] proposes multiple methods to analyze the structure, behavior, and dynamics of business models based on system dynamics, and analyzes the dynamic process of value creation of business models. Hajiheydari and Zarei [84] believe that system dynamics is operational, quantifiable, and flexible in the simulation study of business models. Therefore, the dynamic business model dynamics model based on EBMO model is constructed using this method. The results show that the business model is changed. Decision-making makes complex and dynamic behaviors of the constituent elements of the business model, and at the same time leads to nonlinear and complex changes in other elements. Li Yuying [85] studies the Internet of Things business model based on value network and uses system dynamics to dynamically analyze the model. Zhang Wei and Zhao Liang [86] used system dynamics to study the dynamic evolution of the $\mathrm{O} 2 \mathrm{O}$ business model over time. Dai Ming and Chen Luojun [87] analyze the relationship between various elements in the CSO business model and use system dynamics to simulate the model. You Jianping [88], based on the case study, constructed a system dynamics model of the impact of the business model of real estate companies on the growth of enterprises, and identified the key factors affecting the growth of business models in different periods.

The constituent elements of the business model and the complex relationships between the elements make the dynamic evolution of the analytic business model more complex. If we regard the business model as a complete system consisting of several basic elements (and multiple sub-elements), then the relationship between the elements and even the entire system's dynamic mechanism should be important issues that must be explored [5]. Some scholars use system dynamics to analyze and study the complex elements and dynamic evolution of business models. Dong Shuang [82] studies telecommunications business models based on value networks and uses system dynamics to establish a system dynamics model of telecommunication business models based on value networks. Through the simulation research on the mutual restraint and interaction be- 
tween the various subsystems of the model, the key factors affecting the behavior of the business model system are identified. The author analyzes how values are created in different participants in the value chain. Passed. Grasl [83] proposed multiple methods based on system dynamics to analyze the structure, behavior, and dynamics of business models to determine an optimal structure. The multiplex method uses object-oriented analysis to analyze the structure of business models, and uses system dynamics to analyze the dynamic process of the value creation of business models. Li Yuying [85], starting from the perspective of value creation, takes the value-net-based IoT business model as the research object, uses system dynamics to build a business model model for the Internet of Things, and uses a combination of qualitative and quantitative methods to statically and dynamically model the system. Simulation, this method can help organizers and participants of the business model of the Internet of Things to fully understand the business model of the Internet of Things. Dai Ming and Chen Luojun [79] analyzed the relationship between various elements of the CSO business model, used system dynamics to simulate its operating mechanism, and verified the model with a domestic Huawei company as an example, and obtained a good verification effect. The CSO business model emphasizes the interaction of service flows, cash flows, and information flows among participating parties (businesses, demanders, and subcontractors), but this model does not include key corporate resources and key processes, and therefore requires further development. From the micro perspective, Zhang Wei and Zhao Liang [86] studied the system dynamics model of the $\mathrm{O} 2 \mathrm{O}$ business model, and analyzed through simulation the important factors of the business model elements on customer experience and the ability of the company to obtain. The model emphasizes the importance of business models for companies and does not reflect the role of important factors such as value proposition, value creation, and delivery in business models. Youping Jian [88] believes that the business model and corporate growth as part of a complex system of enterprises should be linked together to study. The author takes the real estate company as a case to construct the system dynamics model of the real estate business model's influence on the company's growth, and studies the four sub-modules of the system dynamics model respectively. Through the simulation, the key factors that have important influence on the company's different periods are obtained.

\section{Conclusions}

This article takes the three stages of the conceptualization, elementalization and patternization of business model research as clues, analyzes the development of B2C e-commerce model in detail, and points out that the two important research directions in the future should be based on system dynamics. The paper has a thorough examination on business modelling, and indicates several possible research directions. The main contribution of this paper is that the dynamic modeling of business models is studied in particular. 
Limitation is found in the paper that, although related research of $\mathrm{B} 2 \mathrm{C}$ e-commerce business models has been reviewed in static to dynamic order in this paper, the research does not cover business models other than $\mathrm{B} 2 \mathrm{C}$, which are highly connected.

\section{Acknowledgements}

This research is supported by Guangdong Province Philosophy and Social Sciences “13th Five-Year Plan” Project (GD17CGL10).

\section{References}

[1] Afuah, A. and Tucci, C. (2001) Internet Business Models and Strategies: Text and Cases. McGraw-Hill/Irwin, New York.

[2] Markides, C. and Charitou, C. (2004) Competing with Dual Business Models: A Contingency Approach. Academy of Management Executive, 18, 22-36. https://doi.org/10.5465/AME.2004.14776164

[3] Li, X.R., Zhang, X., Li, Z.X., Bai, L., Zhang, Q., Zhang, J.X., Qiao, W. and Wang, S.Y. (2016) A Bibliometric Analysis on Business Models. Systems Engineering-Theory \& Practice, 36, 273-287.

[4] Amit, R. and Zott, C. (2001) Value Creation in E-Business. Strategic Management, 22, 493-520. https://doi.org/10.1002/smj.187

[5] Afuah, A. (2004) Business Models: A Strategic Management Approach. McGraw-Hill/ Irwin, New York.

[6] Turban, E., King, D., Lee, L., Liang, T.P. and Turban, D. (2015) Electronic Commerce: A Managerial and Social Networks Perspective. In: Springer Texts in Business and Economics, 8th Edition, Springer-Verlag, German.

[7] Achtenhagen, L., Melin, L. and Naldi, L. (2013) Dynamics of Business Models-Strategizing, Critical Capabilities and Activities for Sustained Value Creation. Long Range Planning, 46, 427-442. https://doi.org/10.1016/j.lrp.2013.04.002

[8] Johnson, M., Christensen, C. and Kagermann, H. (2008) Reinventing Your Business Model. Harvard Business Review, 86, 50-59.

[9] Willenstein, L., van der Valk, T. and Meeus, M. (2007) Dynamics in Business Models: An Empirical Analysis of Medical Biotechnology Firms in the Netherlands. Technovation, 27, 221-232. https://doi.org/10.1016/j.technovation.2006.08.005

[10] Hamel, G. (2000) Leading the Revolution. Harvard Business School Press, Boston.

[11] Osterwalder, A., Pigneur, Y. and Tucci, C. (2005) Clarifying Business Models: Origins, Present, and Future of the Concept. Communications of the Association for Information Science, 16, 1-25.

[12] Yuan, L. (2007) Review of Foreign Business Model Theory Research. Foreign Economy and Management, 29, 17-25.

[13] Yuan, L. (2007) Reconstruction of Business Model Theory System. China Industrial Economics, No. 6, 70-79.

[14] Wei, W., Zhu, W.X. and Lin, G.P. (2012) Business Model Theory Based on Stakeholder Trading Structure. Management World, No. 12, 125-131.

[15] Doganova, L. and Eyquem-Renault, M. (2009) What Do Business Models Do?: Innovation Devices in Technology Entrepreneurship. Research Policy, 38, 1559-1570. https://doi.org/10.1016/j.respol.2009.08.002 
[16] Zott, C., Amit, R. and Massa, L. (2011) The Business Model: Recent Developments and Future Research. Journal of Management, 37, 1019-1042. https://doi.org/10.1177/0149206311406265

[17] Applegate, L. (2001) Emerging E-Business Models: Lessons from the Field. Harvard Business School Press, Boston.

[18] Osterwalder, A. (2004) The Business Model Ontology-A Proposition in a Design Science Approach. University of Lausanne, Switzerland.

[19] Shafer, S., Smith, H. and Linder, J. (2005) The Power of Business Models. Business Horizons, 48, 199-207. https://doi.org/10.1016/j.bushor.2004.10.014

[20] Morris, M., Schindehutte, M. and Allen, J. (2005) The Entrepreneur's Business Model: Toward a Unified Perspective. Journal of Business Research, 58, 726-735. https://doi.org/10.1016/j.jbusres.2003.11.001

[21] Wei, W. and Zhu, W.X. (2009) Discovering Business Models. Mechanical Industry Press, Beijing.

[22] Teece, D. (2010) Business Models, Business Strategy and Innovation. Long Range Planning, 43, 172-194. https://doi.org/10.1016/j.lrp.2009.07.003

[23] Zott, C. and Amit, R. (2010) Business Model Design: An Activity System Perspective. Long Range Planning, 43, 216-226. https://doi.org/10.1016/j.lrp.2009.07.004

[24] Baden-Fuller, C. and Haefliger, S. (2013) Business Models and Technological Innovation. Long Range Planning, 46, 419-426. https://doi.org/10.1016/j.lrp.2013.08.023

[25] Mahadevan, B. (2000) Business Models for Internet-Based E-Commerce: An Anatomy. California Management Review, 42, 55-69. https://doi.org/10.2307/41166053

[26] Xing, X.Q., Tong, Y.Y. and Chen, X.P. (2011) The Business Model of the Bottom of the Pyramid Market: A Multi-Case Study. Management World, No. 10, 108-125.

[27] Ghaziani, A. and Ventresca, M. (2005) Keywords and Cultural Change: Frame Analysis of Business Model Public Talk, 1975-2000. Sociological Forum, 20, 523-559.

[28] Li, F. (2006) What Is E-Business? How the Internet Transforms Organizations. Wiley-Blackwell, Oxford.

[29] Timmers, P. (1998) Business Models for Electronic Markets. Electronic Markets, 8, 3-8.

[30] Weill, P. and Vitale, M. (2001) Place to Space: Migrating to E-Business Models. Harvard Business School Press, Boston.

[31] Huang, C.-Y. and Shyu, J.Z. (2006) Developing E-Commerce Business Models for Enabling Silicon Intellectual Property Transactions. International Journal of Information Technology and Management, 5, 114-133. https://doi.org/10.1504/IJITM.2006.010113

[32] Wang, X.D. and Dong, D.H. (2013) Evaluation of Foreign Business Model Expression Model and Construction of Integrated Expression Model. Foreign Economics and Management, 35, 49-61.

[33] Stewart, D. and Zhao, Q. (2000) Internet Marketing, Business Models, and Public Policy. Journal of Public Policy \& Marketing, 19, 287-296. https://doi.org/10.1509/jppm.19.2.287.17125

[34] Alt, R. and Zimmerman, H.D. (2001) Introduction to Special Section on Business Models. Electronic Markets, 11, 3-9.

[35] Rayport, J. and Jaworski, B. (2000) E-Commerce. McGraw-Hill/Irwin, New York.

[36] Betz, F. (2002) Strategic Business Models. Engineering Management Journal, 14, 
21-28. https://doi.org/10.1080/10429247.2002.11415145

[37] Chesbrough, H., Ahern, S., Finn, M. and Guerraz, S. (2006) Business Models for Technology in the Developing World: The Role of Non-Governmental Organizations. California Management Review, 48, 48-61. https://doi.org/10.2307/41166349

[38] Demil, B. and Lecocq, X. (2010) Business Model Evolution: In Search of Dynamic Consistency. Long Range Planning, 43, 227-246. https://doi.org/10.1016/j.lrp.2010.02.004

[39] Itami, H. and Nishino, K. (2010) Killing Two Birds with One Stone: Profit for Now and Learning for the Future. Long Range Planning, 43, 364-369. https://doi.org/10.1016/j.lrp.2009.07.007

[40] Cheng, Y. and Sun, J.G. (2013) Theoretical Model of the Business Model: Factors and Relationships. China Industrial Economics, No. 1, 141-153.

[41] Grant, D. (2014) Analysis of E-Business Models in Real Estate. Electronic Commerce Research, 15, 25-50.

[42] Tapscott, D., Ticoll, D. and Lowy, A. A Conversation with Don Tapscott, David Ticoll, and Alex Lowy, Authors of Digital Capital: Harnessing the Power of Business Webs.

[43] Gordijn, J. and Akkermans, H. (2001) Designing and Evaluating E-Business Models. IEEE Intelligent Systems, 16, 11-17. https://doi.org/10.1109/5254.941353

[44] Osterwalder, A. and Pigneur, Y. (2004) An Ontology for E-Business Models. In: Currie, W., Ed., Value Creation from E-Business Models, Elsevier, Amsterdam, 65-97. https://doi.org/10.1016/B978-075066140-9/50006-0

[45] Tankhiwale, S. (2009) Exploring the Interrelationship between Telco Business Model Innovation and the Change in Business Process Architecture. Journal of Telecommunications Management, 2, 126-137.

[46] Huizingh, E. (2002) Towards Successful E-Business Strategies: A Hierarchy of Three Management Models. Journal of Marketing and Management, 18, 721-747. https://doi.org/10.1362/0267257022780615

[47] McPhillips, S. and Merlo, O. (2008) Media Convergence and the Evolving Media Business Model: An Overview and Strategic Opportunities. Marketing Review, 8, 237-253. https://doi.org/10.1362/146934708X337663

[48] Eriksson, C., Kalling, T., Åkesson, M. and Fredberg, T. (2008) Business Models for M-Services: Exploring the E-Newspapers Case from a Consumer View. Journal of Electronic Commerce in Organizations, 6, 29-57. https://doi.org/10.4018/jeco.2008040103

[49] Pauwels, K. and Weiss, A. (2008) Moving from Free to Fee: How Online Firms Market to Change Their Business Model Successfully. Journal of Marketing, 72, 14-31. https://doi.org/10.1509/jmkg.72.3.14

[50] Clemons, E. (2009) Business Models for Monetizing Internet Applications and Web Sites: Experience, Theory and Predictions. Journal of Management Information Systems, 26, 15-41. https://doi.org/10.2753/MIS0742-1222260202

[51] Magali, D.-T., Alexander, O. and Yves, P. (2010) E-Business Model Design, Classification, and Measurements. Thunderbird International Business Review, 44, 5-23.

[52] Van der Vorst, J.G.A.J., Van Dongen, S., Nouguier, S. and Hilhorst, R. (2002) E-Business Initiatives in Food Supply Chains: Definition and Typology of Electronic Business Models. International Journal of Logistics. Research and Applications, 5, 119-138. https://doi.org/10.1080/13675560210148641

[53] Desai, B. and Currie, W. (2005) Towards the ASP E-Business Model: A Conceptual 
Framework for Mapping ASP Specific Value Propositions. Journal of Internet Commerce, 4, 79-101. https://doi.org/10.1300/J179v04n01_04

[54] Guo, Z.C. (2016) A Literature Review of Representation Models of E-Business Models from the Perspective of Value Creation. American Journal of Industrial and Business Management, 6, 129-135. https://doi.org/10.4236/ajibm.2016.62013

[55] Zhang, J.W. and Wang, Y.J. (2010) Research on Conceptual Model of Business Model Based on Value Triangle Logic. Foreign Economics and Management, 32, $1-8$

[56] Chesbrough, H. (2007) Why Companies Should Have Open Business Models. MIT Slogan Management Review, 48, 22-28.

[57] Wang, Q. (2011) Enterprise Business Model Innovation Based on Value Network Reconstruction. China Industrial Economics, No. 1, 79-88.

[58] Wei, J., Liu, Y. and Ying, Y. (2012) The Connotation of Business Model and the Construction of Research Framework. Scientific Research Management, 33, 107-114.

[59] Guo, X.-P., Yang, Z. and Luo, X.-H. (2014) Research Review of Business Models and Construction of Theoretical Framework from the Perspective of Value Creation: Encoding and Refinement Based on Grounded Thinking. Foreign Economics and Administration, 36, 32-41.

[60] Magretta, J. (2002) Why Business Models Matter. Harvard Business Review, 80, 86-92.

[61] Linder, J and Cantrell, S. (2000) Changing Business Models: Surveying the Landscape. Working Paper, Accenture Institute for Strategic Change, Boston, MA, 1-15.

[62] Amit, R. and Zott, C. (2012) Creating Value through Business Model Innovation. MIT Slogan Management Review, 53, 41-49.

[63] Casadesus-Masanell, R. and Zhu, F. (2013) Business Model Innovation and Competitive Imitation: The Case of Sponsor-Based Business Models. Strategic Management Journal, 34, 464-482. https://doi.org/10.1002/smj.2022

[64] Osterwalder, A. and Pigneur, Y. (2010) Business Model Generation: A Handbook for Visionaries, Game Changers, and Challengers. John Wiley \& Sons, Hoboken.

[65] Suarez, F., Cusumano, M. and Kahl, S. (2013) Services and the Business Models of Product Firms: An Empirical Analysis of the Software Industry. Management Science, 59, 420-435. https://doi.org/10.1287/mnsc.1120.1634

[66] Peters, C., Blohm, I. and Leimeister, J. (2015) Anatomy of Successful Business Models for Complex Services: Insights from the Telemedicine Field. Journal of Management Information Systems, 32, 75-104. https://doi.org/10.1080/07421222.2015.1095034

[67] Yuan, L. (2008) Research on Classification of Business Models. China Soft Science, No. 5, 35-44.

[68] Anderson, J., Narus, J. and Rossum, W. (2006) Customer Value Propositions in Business Markets. Harvard Business Review, 84, 91-99.

[69] Huff, A., Floyd, S., Sherman, H. and Terjesen, S. (2009) Strategic Management: Logic and Action. John Wiley \& Sons, Hoboken.

[70] Johnson, M. (2010) Seizing the White Space: Business Model Innovation for Growth and Renewal. Harvard Business Press, Boston.

[71] Kiani, B., Gholanmian, R., Hamzehei, A. and Hosseini, S. (2009) Using Causal Loop Diagram to Achieve a Better Understanding of E-Business Models. International 
Journal of Electronic Business Management, 7, 159-167.

[72] Wu, X.B., Ma, R.F. and Shi, Y.J. (2010) How Do Latecomer Firms Capture Value from Disruptive Technologies? A Secondary Business-Model Innovation Perspective. IEEE Transactions on Engineering Management, 57, 51-62. https://doi.org/10.1109/TEM.2009.2033045

[73] Ziber, N. and de Araújo, B. (2012) Small Companies Innovations in Emerging Countries: E-Business Adoption and Its Business Model. Journal of Technology Management \& Innovation, 7, 102-116. https://doi.org/10.4067/S0718-27242012000200009

[74] Zhang, X.H., Williams, A. and Polychronakis, Y. (2012) A Comparison of E-Business Models from a Value Chain Perspective. EuroMed Journal of Business, 7, 83-101. https://doi.org/10.1108/14502191211225392

[75] Giannoutakis, K. and Li, F. (2014) Developing Sustainable E-Business Models for Intelligent Transportation Systems (ITS). Alimentary Pharmacology \& Therapeutics, 40, 200-211.

[76] Ouyang, F. (2007) Structured Analysis of E-Value Based E-Commerce Model: Taking Database Service Provider as an Example. Scientific Management Research, 25, 73-76.

[77] Ouyang, F., Zhao, H.D. and Zheng, G.L. (2008) Simulation Analysis of Network Publishing Business Model Based on E³-Value. China Soft Science, No. 3, 134-139.

[78] Peng, D.H., Jia, T.T., Li, Q.Q. and Zhang, X. (2013) Simulation Analysis of Mobile Commerce Business Model Based on $\mathrm{E}^{3}$-Value. Science Technology and Management, 15, 71-76.

[79] Glova, J., Sabol, T. and Vajda, V. (2014) Business Models for the Internet of Things Environment. Procedia Economics and Finance, 15, 1122-1129. https://doi.org/10.1016/S2212-5671(14)00566-8

[80] Yip, G. (2004) Using Strategy to Change Your Business Model. Business Strategy Review, 15, 17-24. https://doi.org/10.1111/j.0955-6419.2004.00308.x

[81] Zhang, J.W. (2012) Research on the Growth Process of New Firms from the Perspective of Business Model Construction. Nankai University, Tianjin.

[82] Dong, S. (2006) Research on Telecommunication Business Model Based on Value Network. Beijing University of Posts and Telecommunications, Beijing.

[83] Grasl, O. (2009) Business Model Analysis-Method and Case Studies. University of St. Gallen, Switzerland.

[84] Hajiheydari, N. and Zarei, B. (2013) Developing and Manipulating Business Models Applying System Dynamics Approach. Journal of Modelling in Management, 8, 155-170. https://doi.org/10.1108/JM2-11-2011-0058

[85] Li, Y.Y. (2014) Research on Business Model of Internet of Things Based on Value Network. Shandong University, Qingdao.

[86] Zhang, Q. and Zhao, L. (2014) Research on System Dynamics Modeling and Simulation of $\mathrm{O} 2 \mathrm{O}$ Business Model Based on the Customer Experience. Science and Technology Management Research, No. 12, 200-204.

[87] Dai, M. and Chen, L. (2014) CSO Business Model and Its System Dynamics Simulation Research. Soft Science, 28, 119-123.

[88] You, J.P. (2015) The Impact of the Business Model of Chinese Real Estate Enterprises on the Growth of Enterprises Based on System Dynamics. Systems Engineering, 33, 105-113. 